\title{
Peran Kesejahteraan di Tempat Kerja terhadap Kesiapan untuk Berubah
}

\section{Muhammad Noerul Akhbar, Diana Harding, Nurul Yanuarti}

Program Studi Magister Profesi Psikologi, Fakultas Psikologi, Universitas Padjadjaran, Bandung

Abstrak. Salah satu kunci keberhasilan perubahan organisasi ialah faktor sumber daya manusia yang dimilikinya, terutama pada sikap kesiapan untuk berubah (readiness for change). Di sisi lain, perubahan organisasi biasanya menimbulkan emosi negatif bagi karyawan, sehingga karyawan perlu didukung dengan kesejahteraan karyawan di tempat kerja (workplace wellbeing). Oleh karena itu, penelitian ini menguji pengaruh kesejahteraan karyawan di tempat kerja terhadap kesiapan untuk berubah, dengan hipotesis penelitian bahwa terdapat pengaruh kesejahteraan di tempat kerja terhadap kesiapan untuk berubah. Metode penelitian ini menggunakan pendekatan kuantitatif. Penelitian ini dilakukan di salah satu perusahaan BUMN di Indonesia yang sementara ini sedang melakukan beberapa perubahan, dengan jumlah responden penelitian sebanyak 98 karyawan pelaksana yang dipilih menggunakan teknik simple random sampling. Alat ukur penelitian ini menggunakan kuesioner Kesejahteraan di Tempat Kerja dari Maulana (2018) yang diadaptasi dari Workplace Well-Being Index dari Page (2005), dan kuesioner Kesiapan untuk Berubah yang diadaptasi langsung dari Readiness for Change Questionnaire dari Holt et al (2007). Analisis data menggunakan analisis regresi. Hasil penelitian ini menunjukkan terdapat pengaruh yang signifikan $(.00<.05)$ dari kesejahteraan di tempat kerja terhadap kesiapan untuk berubah sebesar 35.5\%.

Kata Kunci: kesejahteraan di tempat kerja, kesiapan untuk berubah, sumber daya manusia

\section{The Role of Workplace Well-Being toward Readiness for Change}

Abstract. One of the keys to the success of organization changes is its human resource factor, especially in readiness for change. On the other hand, organization changes normally could have a negative emotions for employees, so employees should be supported by the well-being of employees in the workplace (workplace well-being). Therefore, this study attempted to examine the effect of workplace well-being on readiness for change, through the research hypothesis which withnessing an effect of workplace well-being on readiness for change. This research method used a quantitative approach. This research was conducted at a state-owned company in Indonesia, which is currently undergoing some organizational changes, as many as 98 participants using simple random sampling techniques. This research measuring instrument by using a Workplace Well-Being questionnaire from Maulana (2018) which was adapted from the Workplace Well-Being Index of Page (2005), and a Readiness for Change questionnaire which was adapted directly from The Readiness for Change Questionnaire of Holt,dkk. (2007). Regression analysis was used to analyze the data. The results of this study imply that there is a significant effect $(.00<.05)$ of workplace well-being on readiness for change of $35.5 \%$.

Keywords: human resources, readiness for change, workplace well-being

Korespondensi: Muhammad Noerul Akhbar. Email: muhammadnoerulakhbar@gmail.com 
Era disruptif pada masa ini ditandai dengan berkembang pesatnya inovasi yang digagas oleh pelaku industri baru, seperti inovasi teknologi dari luring ke daring. Perubahan ini kemudian berdampak terhadap pemenuhan kebutuhan masyarakat zaman sekarang yang semakin mudah dan cepat, sehingga mengubah gaya hidup masyarakat zaman sekarang. Meskipun demikian, perubahan ini berlangsung cepat dan tidak dapat ditolak. Oleh karena itu, hal ini mengancam keberadaan pelaku industri lama yang tidak mampu mengikuti kebutuhan gaya hidup masyarakat zaman sekarang. Era disruptif ini seperti virus yang mewabah dan meluas secara cepat, mulai pada dunia bisnis, perbankan, transportasi, sosial masyarakat, dan hubungan kemasyarakatan, sehingga hanya menyisakan dua pilihan yakni berubah atau punah (Sugiarto, 2018).

Berkenaan dengan hal tersebut, sebagian besar ahli perilaku organisasi sepakat bahwa faktor manusia menjadi anteseden yang paling mungkin menjadi faktor keberhasilan inisiatif perubahan organisasi (Armenakis et al., 1993). Seringkali, proses perubahanlah yang menentukan apakah hasil perubahan akan berhasil atau tidak, misalkan penerimaan dan dukungan dari karyawan sangat penting dalam keberhasilan perubahan organisasi. Oleh karena itu, penting untuk memahami sikap karyawan terhadap perubahan organisasi dalam proses perubahan.
Konsep yang digunakan untuk menjelaskan jenis reaksi dan sikap ini adalah kesiapan untuk berubah (readiness for change). Beberapa ahli berupaya menjelaskan kesiapan untuk berubah, di antaranya Armenakis et al (1993) dengan mendefinisikan kesiapan untuk berubah sebagai keyakinan, sikap, dan intensi individu yang mengarah pada dukungan terhadap perubahan. Kemudian, Hanpachern et al. (1998) menjelaskan bahwa kesiapan untuk berubah ialah sejauh mana individu secara mental, psikologis, maupun fisik siap atau prima untuk berpartisipasi dalam kegiatan pengembangan organisasi. Terakhir, Holt et al (2007) menjelaskan kesiapan untuk berubah sebagai suatu sikap komprehensif yang dipengaruhi secara simultan oleh: (a) apa yang diubah (isi), (b) bagaimana perubahan itu diimplementasikan (proses), (c) keadaan di mana perubahan itu terjadi (konteks), dan (d) karakteristik individu yang diminta untuk berubah (atribut individual). Hal tersebut secara kolektif terefleksikan ke dalam aspek kognitif maupun emosional individu untuk menunjukkan sejauh mana individu cenderung menerima, menganut, dan mengadopsi perubahan untuk mengubah kondisi saat ini.

Konsekuensi dari kesiapan untuk berubah itu sendiri sangat erat terhadap keberhasilan perubahan organisasi. Armenakis et al. (1993) menjelaskan bahwa karyawan yang bersedia dan siap mengadopsi perubahan tentu dapat mengurangi kemungkinan kegagalan dalam menerapkan perubahan. 
Rafferty et al. (2013) menjelaskan bahwa dampak dari kesiapan untuk berubah dapat berupa perilaku dukungan terhadap perubahan (change supportive behaviours), performa kerja (job performance), dan sikap kerja (job attitudes). Oleh karena itu, secara umum, kesiapan untuk berubah meningkatkan keberhasilan implementasi perubahan organisasi. Hal ini juga didukung dari hasil penelitian Hallgrimsson (2008) yang menunjukkan bahwa peningkatan kesiapan untuk berubah dapat meningkatkan implementasi perubahan dalam organisasi.

Ada empat dimensi yang membentuk kesiapan untuk berubah dalam diri individu, yaitu: (a) kesesuaian (appropriateness), (b) dukungan manajemen (management support), (c) efikasi terhadap perubahan (change efficacy), dan (d) keyakinan personal (personal valence) (Holt et al., 2007). Dimensi kesesuaian, yaknimengenai perasaan individu bahwa perubahan yang diajukan akan tepat bagi organisasi atau menjawab kebutuhan organisasi. Dimensi dukungan manajemen, menjelaskan tentang keyakinan individu bahwa para manajer akan mendukung dan berkomitmen terhadap pelaksanaan perubahan. Dimensi efikasi terhadap perubahan, yakni mengenai perasaan individu bahwa ia mampu mengimplementasikan perubahan dengan baik. Dimensi keyakinan personal, menjelaskan mengenai keyakinan individu atas manfaat/keuntungan yang akan didapatkan secara personal apabila perubahan tersebut diimplementasikan.
Ada banyak faktor yang dapat memengaruhi kesiapan untuk berubah pada diri karyawan. Holt et al. (2007) menjelaskan ada empat perspektif yang memengaruhi kesiapan untuk berubah yaitu: isi, konteks, proses, dan atribut individu. Faktor atribut individual menjadi salah satu faktor yang cukup penting memengaruhi kesiapan untuk berubah. Hal ini dikarenakan selama perubahan organisasi, karyawan akan cenderung mengalami emosi negatif, seperti perasaan cemas, stres, dan sebagainya. Maka dari itu, organisasi perlu menjaga kesejahteraan karyawan di tempat kerja (workplace well-being) selama perubahan agar tetap positif untuk membantunya dalam menghadapi perubahan.

Konsep kesejahteraan (well-being) karyawan di tempat kerja merupakan konsep yang cukup luas dengan berbagai pandangan dari para ahli (De Simone, 2014). Tahun 2005, Page (2005) memperkenalkan istilah baru dalam konsep kesejahteraan di tempat kerja yakni workplace well-being. Page (2005) menjelaskan bahwa kesejahteraan di tempat kerja berbeda dengan konsep kesejahteraan dari para ahli sebelumnya yang tidak menyentuh secara spesifik aspek pekerjaan dan tempat pekerjaan itu sendiri. Kesejahteraan di tempat kerja didefinisikan sebagai "an affective sense of well-being resulting from the satisfaction of intrinsic and/ or extrinsic work values". Artinya bahwa kesejahteraan di tempat kerja sebagai rasa 
sejahtera yang dihasilkan dari kepuasan terhadap nilai-nilai intrinsik dan ekstrinsik dari pekerjaan. Kesejahteraan di tempat kerja terdiri dari: afek karyawan secara umum (core affect) dan kepuasan karyawan terhadap nilai intrinsik dan/atau ekstrinsik dari pekerjaan (Page, 2005).

Kesejahteraan di tempat kerja dibangun dari dua dimensi, yakni dimensi intrinsik dan ekstrinsik. Dimensi intrinsik kesejahteraan di tempat kerja terdiri dari aspek-aspek mengenai perasaan karyawan terkait tugas yang dimiliki dalam ranah kerja mereka. Faktor ini terdiri dari lima aspek, yaitu: (a) tanggung jawab dalam kerja, (b) makna pekerjaan, (c) kemandirian dalam pekerjaan, (d) penggunaan kemampuan dan pengetahuan dalam kerja, serta (e) perasaan berprestasi dalam bekerja. Sementara itu, dimensi ekstrinsik kesejahteraan di tempat kerja terdiri dari aspek-aspek mengenai perasaan karyawan terkait lingkungan pekerjaan mereka. Faktor ini terdiri dari delapan aspek, yakni: (a) penggunaan waktu yang sebaik-baiknya, (b) kondisi kerja, (c) supervisi, (d) peluang promosi, (e) pengakuan terhadap kinerja yang baik, (f) penghargaan sebagai individu di tempat kerja, (g) upah, dan (h) keamanan pekerjaan (Page, 2005).

Ada beberapa konsekuensi positif dari karyawan yang memiliki kesejahteraan di tempat kerja, baik dari segi karyawan itu sendiri maupun organisasi. Bagi karyawan, tentunya karyawan akan sehat, hidup seimbang, dan memiliki kesejahteraan psikologis. Bagi organisasi, akan meningkatkan kinerja dan produktivitas karyawan, menurunkan pengunduran diri (turnover), sehingga menjaga karyawan yang bertalenta (Black Dog Institute., 2018). Beberapa penelitian juga membuktikan kontribusi positif kesejahteraan di tempat kerja, seperti penelitian yang dilakukan oleh Mangundjaya (2012) yang menemukan bahwa kesejahteraan di tempat kerja memberikan kontribusi terhadap munculnya keterikatan karyawan dan modal psikologis. Penelitian yang dilakukan Fridayanti et al. (2019) menemukan adanya pengaruh kesejahteraan di tempat kerja terhadap kesehatan mental karyawan. Penelitian yang dilakukan Isham et al. (2020) menjelaskan bahwa kesejahteraan menjadi salah satu pendorong tingkat produktivitas yang lebih tinggi, meskipun hubungan antara pertumbuhan produktivitas dan kesejahteraan melibatkan banyak faktor moderator dan mediator.

Oleh karena itu, tujuan dari penelitian ini ialah untuk melihat pengaruh kesejahteraan di tempat kerja terhadap kesiapan untuk berubah. Sejauh penelusuran yang telah dilakukan, sampai saat ini masih sedikit penelitian terdahulu yang melihat hubungan antara kedua konsep ini di Indonesia, yakni hanya penelitian yang dilakukan oleh Fachruddin dan Mangundjaya (2012) yang menemukan bahwa tidak ada pengaruh kesejahteraan di tempat kerja terhadap 
kesiapan untuk berubah. Penelitian ini mengambil lokasi penelitian pada perusahaan yang sedang melakukan transformasi organisasi. Penelitian ini diharapkan memberikan sumbangan ilmiah untuk memperoleh pemahaman yang lebih mendalam mengenai konsep tentang kesejahteraan di tempat kerja dan kesiapan untuk berubah, serta mengembangkan teori dan menguji secara metodologis pengaruh kesejahteraan di tempat kerja terhadap kesiapan untuk berubah. Penelitian ini juga diharapkan bermanfaat secara praktis sebagai bahan pertimbangan bagi pihak manajemen organisasi dalam mengelola proses transformasi organisasi, terutama terhadap sumber daya manusia yang dimiliki.

\section{Metode}

\section{Subjek penelitian}

Penelitian ini dilakukan di salah satu organisasi Badan Usaha Milik Negara (BUMN) di Indonesia. Organisasi ini sedang melakukan transformasi organisasi, sehingga berdampak juga terhadap perubahan visi-misi organisasi, restrukturisasi, digitalisasi teknologi, dan perubahan kebijakan internal pendukung lainnya. Subjek dari penelitian ini ialah karyawan pelaksana tetap kantor pusat dengan jumlah populasi sebesar 131 karyawan. Cukup besarnya jumlah karyawan sehingga diperlukan proses pengambilan sampel. Oleh sebab itu, untuk menentukan jumlah sampel ideal yang mewakili penelitian, peneliti menggunakan tabel pengukuran jumlah sampel dari tabel Krejcie dan Morgan (1970). Berdasarkan tabel tersebut, jumlah sampel yang diharapkan dalam penelitian ini sebanyak 98 karyawan. Teknik pengambilan sampel yang digunakan dalam penelitian ini menggunakan teknik simple random sampling. Teknik pengambilan sampel ini adalah salah satu metode probability sampling yang memilih subjek penelitian secara acak sehingga tiap subjek memiliki peluang sama untuk dipilih (Dawson, 2007).

\section{Pengukuran}

Metode pengumpulan data pada penelitian ini ialah melalui penyebaran kuesioner dengan tipe kuesioner persepsi diri. Kuesioner penelitian ini menggunakan dua kuesioner, yakni kuesioner Kesejahteraan di Tempat Kerja dari Maulana (Maulana, 2018) yang diadaptasi dari Workplace Well-Being Index dari Page (2005) dan kuesioner Kesiapan untuk Berubah yang diadaptasi langsung dari Readiness for Change Questionnaire dari Holt et al. (2007).

Kuesioner dalam penelitian ini melalui serangkaian tahap untuk mendapatkan properti psikometri yang baik, sehingga alat tes ini dapat diandalkan untuk melihat kondisi kesejahteraan di tempat kerja dan kesiapan untuk berubah karyawan. Beberapa prosesnya, yakni dimulai dengan uji validitas isi dengan melalui penelaahan alat ukur secara keseluruhan. Penelaahan ini meliputi kesesuaian antara butir pernyataan dengan 
dimensi, dan tata bahasa pada setiap butir pernyataan yang mencerminkan representasi dari hal yang hendak diukur. Penelaahan ini melalui penilaian dua ahli yang berlatar belakang profesor dan psikolog di bidang Psikologi Industri dan Organisasi. Setelah itu, dilanjutkan proses validitas melalui uji korelasi butir total (daya diskriminan) dan uji reliabilitas alat tes. Adapun daya diskriminan dari kuesioner Kesejahteraan di Tempat Kerja berkisar dari nilai .427 hingga .824 dengan reliabilitas sebesar 0.896. Sedangkan, validitas kuesioner Kesiapan untuk Berubah berkisar dari nilai .310 hingga .676 dengan reliabilitas sebesar .862 .

\section{Analisis data penelitian}

Analisis data yang digunakan untuk melihat pengaruh kesejahteraan di tempat kerja terhadap kesiapan untuk berubah yakni analisis regresi. Karena menggunakan analisis parametrik, maka diperlukan pemenuhan syarat parametrik, yakni setidaknya data bersifat interval dan memenuhi uji asumsi regresi. Oleh karena itu, beberapa langkah dalam analisis data penelitian ini, yakni dimulai dengan upaya transformasi data dari data ordinal yang didapatkan dari kuesioner penelitian diubah menjadi data interval. Salah satu caranya dengan menggunakan teknik transformasi sederhana Method of Successive Interval (MSI). Kemudian, langkah selanjutnya dilakukan uji asumsi regresi, yakni uji normalitas, linieritas, dan homoskedastisitas. Terakhir, dilakukan analisis regresi untuk uji hipotesis penelitian.

\section{Hasil}

\section{Hasil analisis deskriptif}

Berdasarkan analisis deskriptif, didapatkan data sebagai berikut:

\section{Tabel 1}

Kategorisasi Kesejahteraan di Tempat Kerja Subjek

\begin{tabular}{lcc}
\hline \multicolumn{1}{c}{ Kategori } & $n$ & $\%$ \\
\hline Sejahtera & 40 & 40.82 \\
Cukup sejahtera & 58 & 59.18 \\
Tidak sejahtera & 0 & .00 \\
$N$ & 98 & 100 \\
\hline
\end{tabular}

Berdasarkan Tabel 1, didapatkan bahwa sebagian besar karyawan memiliki kesejahteraan di tempat kerja pada kategori cukup sejahtera yakni sebanyak 58 karyawan (59.18\%). Kemudian, jumlah karyawan yang memiliki kesejahteraan di tempat kerja pada kategori sejahtera sebanyak 40 karyawan (40.82\%). Tidak terdapat karyawan yang memiliki kesejahteraan di tempat kerja pada kategori tidak sejahtera. Hasil tersebut menunjukkan bahwa sebagian besar karyawan merasa cukup sejahtera terhadap pekerjaannya. 
Tabel 2

Perbandingan Rata-Rata Dimensi Kesejahteraan di Tempat Kerja

\begin{tabular}{lcc}
\hline \multicolumn{1}{c}{ Dimensi } & $M$ & Kategori \\
\hline Afek Umum (Core affect) & 4.39 & Tinggi \\
Dimensi Intrinsik & 4.27 & Sedang \\
Dimensi Ekstrinsik & 4.12 & Sedang \\
\hline Catatan. $M$ = Skor rata-rata. & &
\end{tabular}

Berdasarkan Tabel2, didapatkan bahwaafek umum (core affect) memiliki skor rata-rata 4.39 dalam kategori tinggi, dimensi intrinsik memiliki skor rata-rata 4.27 dalam kategori sedang, sementara dimensi ekstrinsik memiliki skor ratarata 4.12 dalam kategori sedang. Hasil tersebut menunjukkan bahwa dimensi yang paling rendah dimiliki karyawan ialah dimensi ekstrinsik.

\section{Tabel 3}

Perbandingan Skor Rata-Rata Aspek Dimensi Intrinsik dan Ekstrinsik Kesejahteraan di Tempat Kerja

\begin{tabular}{clcc}
\hline $\begin{array}{c}\text { Dimensi } \\
\text { kesejahteraan di } \\
\text { tempat kerja }\end{array}$ & \multicolumn{1}{c}{ Aspek-aspek } & $M$ & Kategori \\
\hline & Tanggung jawab dalam kerja & & \\
\hline & Makna pekerjaan & 4.44 & Tinggi \\
Dimensi intrinsik & Kemandirian dalam pekerjaan & 4.68 & Tinggi \\
& Penggunaan kemampuan dan pengetahuan & 4.40 & Tinggi \\
& dalam kerja & 4.46 & Tinggi \\
& Perasaan berprestasi dalam bekerja & 3.36 & Sedang \\
\hline & Penggunaan waktu yang sebaik-baiknya & 4.66 & Tinggi \\
& Kondisi kerja & 4.45 & Tinggi \\
& Supervisi & 4.68 & Tinggi \\
& Peluang promosi & 3.82 & Sedang \\
& Pengakuan terhadap kinerja yang baik & 3.46 & Sedang \\
& Penghargaan sebagai individu di tempat kerja & 4.40 & Tinggi \\
& Upah & 4.04 & Sedang \\
& Keamanan pekerjaan & 3.43 & Sedang \\
\hline
\end{tabular}

Catatan. $M=$ Skor rata-rata.

Berdasarkan Tabel 3, didapatkan bahwa di antara aspek-aspek dalam dimensi intrinsik kesejahteraan di tempat kerja, aspek makna pekerjaan memiliki skor rata-rata tertinggi, diikuti dengan aspek penggunaan kemampuan dan pengetahuan dalam kerja, aspek tanggung jawab dalam pekerjaan, aspek kemandirian dalam pekerjaan, terakhir perasaan berprestasi dalam bekerja. Hasil tersebut menunjukkan bahwa karyawan merasa puas terhadap sebagian besar aspek pekerjaan. Kemudian, berdasarkan Tabel 3, didapatkan pula bahwa di antara aspek-aspek dalam dimensi ekstrinsik kesejahteraan di 
tempat kerja, aspek supervisi menjadi aspek dengan skor rata-rata paling tinggi. Kemudian, diikuti dengan aspek penggunaan waktu sebaik-baiknya, aspek kondisi kerja, dan aspek penghargaan sebagai individu di tempat kerja. Keempat aspek ini berada pada kategori tinggi. Adapun aspek yang masih berada pada kategori sedang yakni aspek upah, aspek peluang promosi, aspek pengakuan terhadap kinerja yang baik, dan terakhir aspek keamanan pekerjaan. Hasil tersebut menunjukkan bahwa karyawan merasa puas terhadap perlakuan dari atasan, waktu kerja, kondisi kerja, dan penghargaan sebagai karyawan. Namun, karyawan masih cukup puas/belum sepenuhnya puas terhadap upah, kesempatan karier, pengakuan dari organisasi terhadap kinerja yang diberikan kepada karyawan, dan posisi pekerjaan karyawan saat ini.

\section{Tabel 4}

Kategorisasi Kesiapan untuk Berubah Subjek

\begin{tabular}{lcc}
\hline \multicolumn{1}{c}{ Kategori } & $n$ & $\%$ \\
\hline Tinggi & 47 & 47.96 \\
Sedang & 51 & 52.04 \\
Rendah & 0 & 0.00 \\
$N$ & 98 & 100 \\
\hline
\end{tabular}

Berdasarkan Tabel 4, didapatkan bahwa sebagian besar karyawan memiliki kesiapan untuk berubah pada kategori sedang yakni sebanyak 51 karyawan (52.04\%). Kemudian, diikuti dengan jumlah karyawan yang berada pada kategori tinggi sebanyak 47 karyawan (47.96\%). Tidak terdapat karyawan yang berada pada kategori rendah. Hasil tersebut menunjukkan bahwa sebagian besar karyawan cukup siap menerima perubahan yang dilakukan organisasinya.

\section{Tabel 5}

Perbandingan Rata-Rata Dimensi Kesiapan untuk Berubah

\begin{tabular}{ccc}
\hline Dimensi & $M$ & Kategori \\
\hline Kesesuaian & 4.60 & Tinggi \\
Dukungan manajemen & 3.90 & Sedang \\
Efikasi terhadap perubahan & 4.30 & Sedang \\
Keyakinan personal & 4.20 & Sedang \\
\hline
\end{tabular}

Catatan. $M=$ Skor rata-rata.

Berdasarkan Tabel 5, didapatkan bahwa dimensi kesesuaian menjadi dimensi tertinggi yang dimiliki karyawan di antara empat dimensi kesiapan untuk berubah. Hasil tersebut menunjukkan bahwa sebagian besar karyawan sudah merasa yakin bahwa 
perubahan yang dilakukan pihak organisasi sudah tepat. Di sisi lain, di antara empat dimensi kesiapan untuk berubah, dimensi dukungan manajemen menjadi dimensi terendah yang dimiliki karyawan. Hasil tersebut menunjukkan bahwa sebagian besar karyawan masih belum sepenuhnya yakin dengan dukungan dan komitmen dari pihak manajemen organisasi terhadap perubahan yang dilakukan.

\section{Hasil analisis hipotesis}

Berdasarkan analisis regresi, didapatkan hasil sebagai berikut:

\section{Tabel 6}

Hasil Uji Regresi Kesejahteraan di Tempat Kerja terhadap Kesiapan untuk Berubah

\begin{tabular}{ccc}
\hline Variabel & $p$ & $R^{2}$ \\
\hline $\begin{array}{c}\text { Kesejahteraan di tempat kerja * Kesiapan } \\
\text { untuk berubah }\end{array}$ & $.00^{*}$ & .355 \\
\hline
\end{tabular}

Catatan. *signifikansi pada $p<.05$.

Berdasarkan Tabel 6, diperoleh hasil bahwa kesejahteraan di tempat kerja berpengaruh signifikan terhadap kesiapan untuk berubah $(<.05)$. Hasil tersebut menunjukkan bahwa rasa sejahtera karyawan yang diperoleh dari pekerjaannya berkontribusi terhadap peningkatan kesiapan karyawan dalam menerima perubahan yang dilakukan organisasi. Adapun besar kontribusi kesejahteraan di tempat kerja terhadap pembentukan kesiapan untuk berubah dalam diri karyawan sebesar 35.5\%. Sementara, sebesar $64.5 \%$ dari kesiapan untuk berubah yang dimiliki karyawan dipengaruhi oleh faktor atau variabel lain yang tidak diteliti dalam penelitian ini.

\section{Pembahasan}

Penelitian ini bertujuan untuk menguji pengaruh kesejahteraan karyawan di tempat kerja terhadap kesiapan untuk berubah. Keberhasilan organisasi mengacu pada sikap karyawan, baik sikap terhadap diri sendiri, terhadap pekerjaan, maupun terhadap kondisi lingkungan kerja (Moorhead \& Griffin, 1995). Tentunya, sikap karyawan terhadap pekerjaan menjadi poin utama dalam mencapai tujuan organisasi, termasuk perubahan yang dilakukan organisasi. Salah satu sikap karyawan yang dibutuhkan dalam proses perubahan organisasi ialah kesiapan karyawan mengikuti perubahan organisasi atau yang biasa dikenal sebagai kesiapan untuk berubah. Peran kesiapan untuk berubah karyawan dalam proses perubahan organisasi dapat dikatakan sebagai sentral, baik dari perspektif konsolidasi perubahan dan dari kemungkinan keberhasilan di masa depan dari program perubahan yang sedang berlangsung. Hal ini mengingat bahwa salah satu alasan mendasar 
mengapa upaya perubahan organisasi sangat sulit dicapai adalah faktor individu dalam organisasi (Ahmad \& Aworinde, 2019; Devos et al, 2002). Oleh karena itu, penting untuk mengidentifikasi variabel yang berkontribusi terhadap kesiapan untuk berubah. Salah satu variabel yang dinilai penting untuk diteliti adalah kesejahteraan di tempat kerja.

Berdasarkan hasil pengujian hipotesis yang dapat dilihat di Tabel 6, didapatkan bahwa terdapat pengaruh kesejahteraan di tempat kerja terhadap kesiapan untuk berubah. Artinya, kesejahteraan di tempat kerja yang dimiliki karyawan berkontribusi terhadap peningkatan kesiapan untuk berubah dalam diri karyawan. Dengan didapatkan koefisien determinasi sebesar .355, hal ini menunjukkan bahwa kontribusi kesejahteraan di tempat kerja terhadap kesiapan untuk berubah sebesar 35.5\%. Sementara, sebesar $64.5 \%$ dari kesiapan untuk berubah dipengaruhi oleh faktor atau variabel lain yang tidak diteliti dalam penelitian ini.

Hasil penelitian ini sesuai pandangan Holt et al. (2007) dengan menjelaskan bahwa terdapat empat perspektif yang memengaruhi kesiapan untuk berubah yaitu: (a) atribut dari inisiatif perubahan yang akan diimplementasikan (perspektif isi), (b) atribut dari lingkungan dimana inisiatif perubahan akan diimplementasikan (perspektif konteks), (c) langkah-langkah yang diambil dalam mengimplementasikan inisiatif perubahan (perspektif proses), dan (d) atribut atau karakteristik individu yang akan mengimplementasikan inisiatif perubahan (perspektif atribut individual). Dalam hal ini, kesehateraan di tempat kerja menjadi salah satu variabel dalam faktor atribut individual. Hal ini juga didukung dari hasil penelitian Yamin dan Handoyo (2014) dengan menemukan bahwa faktor yang memengaruhi kesiapan untuk berubah dapat dikategorikan menjadi dua faktor, yakni faktor individu dan faktor tempat kerja.

Kesejahteraan di tempat kerja merupakan rasa sejahtera yang dihasilkan dari kepuasan karyawan terhadap nilai-nilai intrinsik dan ekstrinsik dari pekerjaan mereka. Oleh sebab itu, hal ini kemudian menghasilkan derajat perasaan sejahtera di tempat kerja yang dapat berbeda-beda pada tiap karyawan. Kesejahteraan di tempat kerja yang dimiliki karyawan kemudian akan berkontribusi terhadap munculnya sikap positif karyawan terhadap organisasi. Dalam hal ini, jika karyawan merasa sejahtera di tempat kerjanya, rasa sejahtera ini kemudian memunculkan sikap positif karyawan, seperti keterikatan karyawan (employee engagement). Hal ini didukung dari hasil penelitian Mangundjaya (2011) dan Kurniadewi (2017) dengan menemukan bahwa terdapat pengaruh signifikan kesejahteraan di tempat kerja terhadap keterikatan karyawan. Adapun ciri karyawan yang terikat ialah: (a) karyawan lebih percaya kepada organisasi, (b) tertarik bekerja lebih, dan (c) selalu mengikuti perkembangan 
yang ada di lapangan (Alagona \& Simon, 2010; Robinson et al., 2004; Verèiè \& Vokiæ, 2017). Meskipun karyawan bekerja lebih, mereka mengalami emosi positif seperti rasa bahagia, antusias, dan optimis (Bakker \& Demerouti, 2008). Oleh karena itu, karyawan yang terikat memiliki penilaian yang positif terhadap diri dan organisasi serta memiliki reaksi afektif yang positif, seperti harapan dan optimisme.

Pada situasi perubahan organisasi, adanya penilaian positif karyawan terhadap organisasi memengaruhi kesiapan perubahan kognitif (cognitive change readiness) dalam diri karyawan. Karyawan memiliki pandangan positif terhadap perubahan yang dilakukan organisasi. Karyawan menilai perubahan yang dilakukan pihak manajemen organisasi adalah hal yang pantas, tepat, dan bermanfaat. Sementara, adanya afektif yang positif dalam diri karyawan memengaruhi kesiapan perubahan afektif (affective change readiness) dalam diri karyawan. Karyawan tetap mampu merasa bahagia dan optimis terhadap segala perubahan yang dilakukan organisasi. Oleh sebab itu, dengan adanya kesiapan perubahan kognitif dan afektif dalam diri karyawan, mereka menjadi lebih siap menerima perubahan yang dilakukan organisasi. Kesiapan perubahan kognitif dan afektif ini sendiri merupakan dua aspek yang merefleksikan sejauh mana karyawan cenderung menerima perubahan yang dilakukan organisasi (Holt et al, 2007; Rafferty et al., 2013). Adanya pengaruh keterikatan karyawan terhadap kesiapan untuk berubah didukung dari hasil penelitian Zulkarnain dan Hadiyani (2014) dengan menemukan bahwa terdapat pengaruh signifikan keterikatan karyawan terhadap kesiapan untuk berubah karyawan. Dengan demikian, secara konseptual, adanya pengaruh kesejahteraan di tempat kerja yang dimiliki karyawan terhadap munculnya kesiapan untuk berubah karyawan dapat dijelaskan melalui keterikatan karyawan.

Berdasarkan hasil penelitian ini, sebagian besar karyawan merasa cukup sejahtera dengan apa yang diberikan organisasi, baik dari aspek pekerjaan itu sendiri maupun dari aspek lingkungan pekerjaan yang dapat dilihat di Tabel 1. Pada situasi perubahan organisasi saat ini, rasa sejahtera karyawan yang didapatkan dari organisasi kemudian berkontribusi dalam memunculkan sikap positif karyawan terhadap organisasi, salah satunya kesiapan untuk berubah. Karyawan yang merasa cukup sejahtera di organisasi menjadi cenderung cukup siap menerima perubahan yang dilakukan organisasi sebagaimana dapat dilihat di Tabel 4. Hal tersebut dikarenakan karyawan yang merasa cukup sejahtera dari pekerjaannya membuat mereka cukup terikat terhadap pekerjaannya. Karyawan berusaha menyelesaikan tugas yang diberikan, meskipun belum proaktif terhadap pekerjaanya dikarenakan masih belum terikat sepenuhnya. Oleh sebab itu, walaupun saat ini ada tuntutan perubahan dari organisasi, karyawan yang 
merasa cukup sejahtera terhadap pekerjaannya memilih tetap berusaha mengikuti kebijakan perubahan organisasi daripada melakukan resistensi terhadap perubahan, meskipun karyawan masih belum proaktif terhadap perubahan tersebut.

Sebagian besar karyawan merasa cukup sejahtera dikarenakan masih ada beberapa aspek yang belum memuaskan karyawan, terutama di dalam dimensi ekstrinsik yang dapat dilihat di Tabel 2 dan 3. Hal ini menunjukkan bahwa karyawan masih belum sepenuhnya sejahtera terhadap aspek-aspek lingkungan pekerjaannya (dimensi ekstrinsik) saat ini dibandingkan dengan aspek pekerjaannya (dimensi intrinsik) itu sendiri. Berdasarkan perbandingan skor rata-rata tiap aspek di antara dimensi ekstrinsik yang dapat dilihat di Tabel 3, didapatkan bahwa karyawan masih merasa cukup puas terhadap aspek peluang promosi, pengakuan atas kinerja yang baik, dan keamanan pekerjaan. Ketiga aspek ini tampak berkaitan erat dengan kebijakan dari pihak manajemen organisasi.

Transformasi organisasi yang dilakukan pihak manajemen pada umumnya membutuhkan penyelarasan pilar-pilar model operasional organisasi yang mencakup struktur dan tata kelola, proses penilaian kinerja, proses bisnis, dukungan teknologi, rekonfigurasi sumber daya, serta pengembangan kemampuan dan budaya organisasi (Pratama, 2015). Dengan demikian, transformasi organisasi biasanya menuntut pihak manajemen perlu menerapkan efisiensi keuangan yang berdampak terhadap pengurangan keuntungan karyawan dan perubahan sistem manajemen Sumber Daya Manusia (SDM) seperti penilaian kinerja maupun sistem karier dalam rangka rekonfigurasi SDM yang tepat untuk mendukung tujuan perubahan. Oleh karena itu, pertanyaan-pertanyaan yang biasanya muncul dalam benak karyawan ketika organisasi melakukan perubahan, seperti bagaimana dengan karier/posisi saya selanjutnya, bagaimana gaji saya dibandingkan dengan orang lain, dan sebagainya. Dengan kata lain, adanya perubahan organisasi menimbulkan emosi negatif dalam diri karyawan seperti kecemasan, rasa tidak aman, dan kepercayaan yang rendah (Buono \& Bowditch, 1989). Berkenaan dengan hasil penelitian ini, masih adanya keluhan karyawan terhadap beberapa aspek dalam dimensi ekstrinsik kesejahteraan di tempat kerja kemudian memengaruhi penilaian karyawan. Dalam hal ini, karyawan menjadi ragu atau masih kurang yakin dengan komitmen dan dukungan pihak manajemen organisasi terhadap perubahan (management support) yang dapat dilihat di Tabel 5.

Penilaian karyawan yang belum yakin sepenuhnya dengan dukungan dari pihak manajemen organisasi berdampak pula terhadap efikasi perubahan karyawan. Berdasarkan Tabel 5, karyawan masih merasa belum sepenuhnya yakin dengan kemampuan 
yang dimilikinya saat ini untuk menyukseskan perubahan. Hal ini disebabkan salah satunya karena karyawan merasa masih kurang didukung dengan fasilitas pelatihan dan pengembangan diri oleh pihak manajemen organisasi agar karyawan bisa menyesuaikan diri dengan tuntutan perubahan. Hal ini sesuai pandangan Rafferty et al. (2013) yang menjelaskan bahwa penilaian karyawan terhadap dukungan manajemen akan berpengaruh terhadap efikasi terhadap perubahan pada karyawan. Selain itu, penilaian karyawan yang belum yakin sepenuhnya dengan dukungan dari pihak manajemen organisasi tampaknya berdampak juga terhadap keyakinan personal karyawan. Berdasarkan Tabel 5, karyawan masih belum sepenuhnya yakin dengan manfaat yang akan didapatkan setelah mengimplementasikan perubahan. Hal ini bisa jadi disebabkan salah satunya karena karyawan merasa efisiensi keuangan yang diterapkan oleh pihak manajemen organisasi justru mengurangi keuntungan yang didapatkan karyawan seiring perubahan yang dilakukan organisasi.

Berdasarkan hasil dan pembahasan, maka perlu dilakukan peningkatan kesejatheraan di tempat kerja, terutama terhadap dimensi ekstrinsik dan aspek khusus di dalamnya sebagai upaya untuk meningkatkan kesiapan untuk berubah pada subjek penelitian. Peningkatan kesiapan untuk berubah pada diri karyawan diharapkan akan membuat karyawan menerima, merangkul, dan mengadopsi perubahan yang diusulkan pihak manajemen organisasi, sehingga akan mendorong performa kerja karyawan yang pada akhirnya akan dapat mengurangi kemungkinan kegagalan dalam menerapkan perubahan.

Hasil penelitian ini berbeda dengan hasil penelitian sebelumnya yang dilakukan oleh Fachruddin dan Mangundjaya (2012) yang menemukan tidak terdapat pengaruh dari kesejahteraan di tempat kerja terhadap kesiapan untuk berubah. Hal tersebut bisa jadi disebabkan oleh beberapa faktor sesuai pandangan Holt et al. (2007), yaitu: (a) karakteristik organisasi (perspektif konteks) yang berbeda, dalam hal ini penelitian sebelumnya dilakukan di perusahaan swasta minyak dan gas bumi, sementara penelitian ini dilakukan di perusahaan BUMN; (b) konten perubahan yang berbeda dari organisasi (perspektif isi); dan (c) proses atau langkahlangkah yang diambil masing-masing pihak manajemen organisasi dalam mengimplementasikan perubahan (perspektif proses) tentu berbeda. Selain itu, hasil penelitian yang berbeda dengan penelitian sebelumnya kemungkinan disebabkan karena pengambilan data dari kedua penelitian ini dilakukan dengan menggunakan kuesioner persepsi diri, sehingga data yang didapatkan sangat bergantung dengan penilaian subjek penelitian itu sendiri.

Keterbatasan dalam penelitian ini adalah proporsi sampel di setiap bagian/departemen 
belum seimbang atau tidak merata, sehingga tidak semua karyawan dari berbagai level tercakup sebagai subjek penelitian. Selain itu, subjek dalam penelitian ini hanya mengambil dari salah satu perusahaan BUMN, sehingga hasil penelitian ini kurang representatif terhadap kondisi perusahaan lain.

\section{Simpulan}

Berdasarkan temuan penelitian, didapatkan bahwa kesejahteraan di tempat kerja yang dimiliki karyawan berkontribusi terhadap kesiapan untuk berubah karyawan. Dengan kata lain, karyawan yang merasa sejahtera terhadap pekerjaannya, akan membuat karyawan lebih siap dalam menghadapi perubahan organisasi. Berbagai penelitian juga telah membuktikan kontribusi kesejahteraan di tempat kerja dalam memunculkan sikap positif karyawan terhadap organisasi, seperti komitmen, keterikatan terhadap organisasi, dan sebagainya. Oleh karena itu, organisasi memang perlu memperhatikan aspek kesejahteraan karyawan di tempat kerja, khususnya selama perubahan dilakukan.

\section{Saran}

Terdapat beberapa saran bagi peneliti lain yang berminat mengkaji mengenai topik dalam penelitian ini. Pertama, melihat kontribusi kesejahteraan di tempat kerja terhadap kesiapan untuk berubah hanya sebesar 35,5\%, sehingga diharapkan penelitian selanjutnya dapat mempertimbangkan faktor-faktor lain yang dapat berpengaruh terhadap kesiapan untuk berubah, seperti keterikatan karyawan, dukungan organisasi, dan lainnya. Kedua, penelitian selanjutnya diharapkan lebih melakukan kontrol terhadap faktor lainnya yang dapat memengaruhi kesiapan untuk berubah, seperti konten perubahan, proses perubahan, hingga jenis organisasi. Ketiga, penelitian selanjutnya diharapkan menggunakan teknik proportionate stratified random sampling dengan tujuan untuk membandingkan kondisi karyawan antar bagian/departemen dan melibatkan karyawan dari berbagai level dalam organisasi. Sehingga, hasil penelitian dapat lebih menggambarkan kondisi keseluruhan karyawan dalam organisasi.

\section{Referensi}

Ahmad, A. H., \& Aworinde, O. B. (2019). Are fiscal deficits inflationary in African countries? A new evidence from an asymmetric cointegration analysis. North American Journal of Economics and Finance, 50. https://doi.org/10.1016/ j.najef.2019.100999

Armenakis, A., Harris, S., \& Mossholder, K. (1993). Creating readiness for organizational change. Human Relations, 46, 681-704. https://doi.org/10.1177/ 001872679304600601

Bakker, A. B., \& Demerouti, E. (2008). Towards a model of work engagement. Career Development International, 13(3), 209223. https://doi.org/10.1108/ 13620430810870476

Black Dog Institute. (2018). Workplace wellbeing. Resource and Support https:/ 
/www.blackdoginstitute.org.au/ resources-support/wellbeing/ workplace-wellbeing/

Buono, A. F., \& Bowditch, J. L. (1989). The Human Side of Mergers and Acquisitions, Managing Collisions Between People, Cultures, and Organizations. Beard Books.

Dawson, C. (2007). A practical guide to research methods 3ed. How to books.

De Simone, S. (2014). Conceptualizing wellbeing in the workplace. International Journal of Business and Social Science, 5(12), 118-122. http://ijbssnet.com/ journal/index/2963

Devos, G., Vanderheyden, K., \& Broek, H. D. (2002). A framework for assesing commitment to change: Process and context variables of organizational change. In Vlerick Leuven Gent Management School Working Paper Series. https://repository.vlerick.com/ handle/20.500.12127/757

Fachruddin, D. F., \& Mangundjaya, W. H. (2012). The impact of workplace well-being and psychological capital, to the individual readiness for change. Proceedings 4 th Asian Psychological Association, 1-18. http://staff.ui.ac.id/system/files/users/ wustari/publication/workplace_wellbeing_psychological_capital_to_irfc.pdf

Fridayanti, F., Kardinah, N., \& Fitri, T. (2019). Peran workplace well-being terhadap mental health: Studi pada karyawan disabilitas. Psympathic/ : Jurnal Ilmiah Psikologi, 6(20), 191-200. https:// doi.org/10.15575/psy.v6i2.5754

Hallgrimsson, T. (2008). Organizational change and change readiness: Employees' attitudes during times of proposed merger [University of Tromso]. https:// munin.uit.no/handle/10037/1542

Hanpachern, C., Morgan, G. A., \& Griego, O. V. (1998). An extension of the theory of margin: A framework for assessing readiness for change. Human Resource Development Quarterly, 9(4), 45-56.
Holt, D. T., Armenakis, A. A., Feild, H. S., \& Harris S. G. (2007). Readiness for organizational change; The systematic development of a scale. The Journal of Applied Behavioral Science, 43(2), 232-255. https://doi.org/ $10.1177 / 0021886306295295$

Isham, A., Mair, S., \& Jackson, T. (2020). Wellbeing and productivity: A review of the literature. In CUSP Working Paper Series (No. 22). https://www.cusp.ac.uk/ themes/s1/wp22/

Krejcie, R. V, \& Morgan, D. W. (1970). Determining sample size for research activities. Educational and Psychological Measurement, 30(3), 607-610. https:// d o i . o r g / 10 . 1177 / 001316447003000308

Kurniadewi, E. (2017). Psychological capital dan workplace well-being sebagai prediktor bagi employee engagement. Jurnal Psikologi Integratif, 4(2), 95-112. https://doi.org/10.14421/jpsi.2016.4202

Mangundjaya, W. L. (2011). Pengaruh workplace well-being terhadap psychological capital dan employee engagement Proceedings: Strategic Roles of I/O Psychology in Building Creative Society. https://www.academia.edu/ 7182903/Pengaruh_Workplace_Well_ Being_terhadap_Psychology_Capital_dan_ Employee_Engagement

Maulana, F. (2018). Pengaruh workplace wellbeing terhadap intensi turnover pada karyawan [Universitas Muhammadiyah Malang]. http://eprints.umm.ac.id/ 39591/

Moorhead, G., \& Griffin, R. W. (1995). Organizational behaviour: Managing people and organizations. Mifflin company.

Page, K. M. (2005). Subjective well-being in the workplace. Deakin University.

Pratama, A. (2015). Manajemen perusahaan: transformasi yang paripurna. In m.bisnis.com. https://m.bisnis.com/ 
amp/read/20150920/237/474342/ manajemen-perusahaantransformasiyang-paripurna.

Rafferty, A. E., Jimmieson, N. L., \& Armenakis, A. A. (2013). Change readiness: A multilevel review. Journal of Management Studies, 39(1), 110-135. h t tp s: / / do i.org / 10.1177 / 0149206312457417

Robinson, D., Perryman, S., \& Hayday, S. (2004). The drivers of employee engagement report. Institute for Employment Studies. h t tp s: / / w w w. e m ploymentstudies.co.uk/resource/driversemployee-engagement

Simon, H. (2010). Engaging employees through whole leadership. Strategic HR Review, 9(3), 11-17. https://doi.org/10.1108/ 14754391011040028

Sugiarto, E. C. (2018). Disrupsi dan Humas Pemerintah 4.0. Kementrian Sekretariat Negara Republik Indonesia. https:// s e tn e g.go.id / b a c a / i n de x / disrupsi_dan_humas_pemerintah_40
Verèiè, A. T., \& Vokiæ, N. P. (2017). Engaging employees through internal communication. Public Relations Review, 43(5), 885-893. https://doi.org/ 10.1016/j.pubrev.2017.04.005

Yamin, A., \& Handoyo, S. (2014). Faktor-faktor yang mempengaruhi readiness for change pada pekerja di PT. X area Jatim dan Balinus. Insan Media Psikologi, 16(3), 1-13. http://journal.unair.ac.id/ INSAN@faktor-faktor-yangmempengaruhi-readiness-for-changepada-pekerja-di-pt-x-area-jatim-danbalinus-article-10522-media-8category-10.html

Zulkarnain, \& Hadiyani, S. (2014). Peranan komitmen organisasi dan employee engagement terhadap kesiapan karyawan untuk berubah. Jurnal Psikologi, 41(1), 17-33. https://doi.org/ 10.22146/jpsi.6955

Received 7 February 2020 Revised 27 February 2020 Accepted 30 May 2020 